\title{
Negative Capability and Religious Experience
}

\author{
Gavin Hopps \\ School of Divinity, University of St Andrews, Scotland \\ gavin.hopps@st-andrews.ac.uk
}

\begin{abstract}
This article responds to each of the four essays on The Extravagance of Music in turn. It addresses the particular issues they raise, though a prominent contention running through the piece concerns the need for what André Gide calls 'une disposition à l'accueil' - that is, a posture of receptivity or hospitable disposition in relation to the revelatory potential of music. In explaining the importance of this openness to possibilities - which I argue should be 'ecumenically' extended to all types of music - the chapter invokes Keats's notion of 'negative capability' and affirms, against approaches that seek to predetermine the theological meanings of music, the value in religious contexts of this willingness to dwell hospitably with indeterminacy.
\end{abstract}

Keywords: popular music, transcendence, general revelation, hospitality, the autonomy of affect, affordance 


\title{
Negative Capability and Religious Experience
}

\author{
Philosophy, like life, must keep the doors and windows open.
}

(William James)

It was with an intermingled sense of gratitude and regret that I read the foregoing essays: gratitude for the time and trouble the contributors have evidently taken to read and reflect on our co-written book with such generosity and in an array of provocative and illuminating ways; regret that I couldn't attend the conference where the papers were first aired and interact with the contributors in person. The following, necessarily foreshortened remarks are therefore offered as a kind of esprit de l'escalier, joining in as it were after the event, but also as an addendum to the book itself. ${ }^{1}$

Whilst there is an abundance of riches here, in responding to the essays I shall limit myself to a few key points in each piece, picking up things that seem to require clarification, addressing questions and points of criticism, but also highlighting issues that appear to have been overlooked. (I shall in places refer to the original conference talks as well as the extended versions published here, since some of the latter were only made available shortly before the deadline for submission.) Naturally enough, some of the contributions are more contentious than others, and certain points require more extensive clarification, so I can only apologise in advance for the unevenness of length in my responses to the essays.

Christoph Schwöbel's characteristically erudite and urbane paper, though perhaps the most critical, helpfully homes in on a number of central contentions in the book. His piece therefore suggests itself as a good place to begin. Since my co-author responds to Schwöbel's proposal of a 'Lutheran' understanding of music, I shall only mention a couple of brief additional thoughts relating to that section. One was that affect theory has moved on somewhat since Luther was writing. This is especially the case with respect to the kind of predetermined lists of musical effects to which Schwöbel alludes. Indeed, most contemporary theorists in the field would prefer to emphasize the transversal freedom or autonomy of affect - that is, its promiscuous openness to heterogeneous alliances. (Suzanne Cusick's well-known eroticized response to Bach's 'Vom Himmel hoch da komm' ich her', discussed by Heidi Epstein in her contribution, is a vivid illustration of the unpredictable freedom of affects, even in relation to explicitly religious works.) The other point relates to Schwöbel's approving quotation of the composer Mauricio Kagel's claim that 'all musicians believe in Bach'. Really, all? Dolly Parton? The Happy Mondays? N.W.A.? Showaddywaddy? Perhaps Kagel and Schwöbel would not consider such artists to be 'musicians'; however, that would seem to be an even harder view to defend. Either way, such comments suggest a prejudicially circumscribed sense of what constitutes 'music' or 'serious music', to which I shall return.

The first larger issue I would like to pick up is what Schwöbel refers to as the 'hidden compliment' the book pays to Jeremy Begbie, for putting 'the topic of the relationship between music and theology on the agenda in such a provocative and surprising way'. I agree with this and am glad of the opportunity to reaffirm it. Jeremy and I were colleagues at St Andrews for a number of years and I learnt a great deal from him, not only about music but also about the relationship between theology and the arts more generally. I hadn't, however, thought of the compliment as hidden, in part because I explicitly praise his work for precisely these reasons

\footnotetext{
${ }^{1}$ I would like to take this opportunity to say thank you to Awet Andemicael, who proposed, organized and chaired the event with such gracious proficiency.
} 
at the outset of my discussion, ${ }^{2}$ though I also thought it was fairly clear that I engage at length and in detail with his work because I consider him to be such a leading figure in the field.

It is, in addition, worth pointing out - since what Schwöbel advocates is further dialogue - that the approach set out in the book is proposed as an 'as well as' rather than an 'instead of'. ${ }^{3}$ I therefore concur with Schwöbel's suggestion that a 'hermeneutic of dialogical exchange' is to be desired. The problem here though is that Begbie seems to be rather less dialogically inclined. Indeed, in a flurry of recent essays, he takes up arms against approaches that differ from his own (in one of these he describes his comments as 'warning shots across the bow' of these 'fashionable theological steamers ${ }^{3}$ ) and appears to present his predermining methodology as the only properly theological approach to music. ${ }^{5}$ Kutter, take heart, you are by no means the only one that Begbie isn't into! ${ }^{6}$

There is something else though that also inhibits the conversation - and that is Begbie's distaste for popular music. ${ }^{7}$ Perhaps Schwöbel doesn't mention this because he shares Begbie's illiberal views about this sort of music ${ }^{8}$ (though Luther had a soft spot for popular songs and seemed to think music as such was capable of beneficently lifting our spirits). In any case, as long as the whole 'incorrigibly plural' sphere of popular music is shunned or treated as a second-class artform, it is hard to see how inclusive and constructive dialogue about music and its theological affiliations would be possible. ${ }^{9}$

\footnotetext{
${ }^{2}$ The Extravagance of Music, 186-8.

${ }^{3}$ Ibid., 188. It may be helpful to clarify that I am not at all opposed to instrumental or catechetical approaches that is, instructional methods that use art to illustrate what the theologian already knows. Whilst such approaches have limited uses and may be criticized for neglecting the possibility that a divergence from theological teaching might also provoke constructive engagement, they can nonetheless serve a valuable purpose in providing new and illuminating ways of thinking about matters of doctrine, as Begbie shows in his essay 'Through Music', in Beholding the Glory (2001). What I do see as problematical though is the abstract pre-allocation of theological meaning to aesthetic features, which forms part of this catechetical strategy in the approach that Begbie advocates. The problems with this theological pre-chewing of our food are addressed below.

4 'The Future of Theology amid the Arts: Some Reformed Reflections', in Christ across the Disciplines: Past, Present, Future, ed. Roger Lundin (Grand Rapids: Eerdmans, 2013), 156.

${ }^{5}$ See, for instance, his comments on David Brown's work in 'Openness and Specificity: A Conversation with David Brown on Theology and Classical Music', in Theology, Aesthetics and Culture: Responses to the Work of David Brown, ed. Robert MacSwain and Taylor Worley (Oxford: Oxford University Press, 2012), 145-56. This impression is reinforced by his consistently negative evaluations of alternative approaches, such as those espoused by Albert Blackwell, William Dyrness, Anthony Monti, Philip Stoltzfus and Richard Viladesau, all of which are summarily deemed to be 'unconvincing'.

${ }^{6}$ The original title of Callaway's contribution was: 'He's Just Not That Into You'.

${ }^{7}$ To my knowledge, Begbie doesn't explain anywhere in print his reasons for consistently keeping popular music at arm's length in a series of studies purporting to be about music in general. The impression this gives that he considers it to be unworthy of serious attention is reinforced by his denunciation of 'light' and 'sentimental' music, which he considers to be a 'pernicious' form of culture ('Beauty, Sentimentality and the Arts', in The Beauty of God: Theology and the Arts, ed. Daniel J. Treier et al. (Downers Grove, IL: InterVarsity Press, 2007), 45). In my experience, academics who look down on popular music - or who more discreetly assume that, really, as we all of course know, classical music is much more important - tend to have a very limited knowledge of the music they disdain. The late Sir Roger Scruton, for example, who at least came clean about his aversion to popular music and tried to give reasons in defence of his views, was happy to make sweeping evaluative pronouncements about it whilst at the same time acknowledging that he actively sought to avoid such music. It would be interesting to hear from Begbie about what it is he has against popular music.

${ }^{8}$ Gerald Liu goes further and accuses Begbie of 'sonic xenophobia', on account of his consistent privileging of 'Western serious tonal music' and for deeming other kinds of music unfit for theological inquiry (Music and the Generosity of God (London: Palgrave, 2017), 123).

${ }^{9}$ I worry too about the recurrent use of the music of J.S. Bach as an exemplar, in Begbie's work but also in Schwöbel's chapter here, which sets up a very particularized standard, against which other kinds of music are measured - and inevitably found wanting. For it may be the case that this failure to measure up is the result of a divergence of aims and a sign that they aspire to other models of aesthetic accomplishment.
} 
The other, more complicated issue that Schwöbel raises concerns the conception of transcendence advocated in the book. In summary, the problem with this for Schwöbel is that it is underdetermined ("Whose transcendence are we talking about? Transcendence is an incomplete concept, like an incomplete symbol in logic, it requires further clarification. It requires to filled out by the identity of the God whose transcendence we are invoking'). This is of course a hugely complicated issue which I can only deal with very broadly here. However, it seems to me that Schwöbel has missed the point, and in two respects. Firstly, what I am primarily concerned with in the book are experiences of general revelation, which are by their very nature underdetermined. That is to say, they are fugitive, vesperal intimations of presence or a something 'more' at the heart of being, which are distinct from but not incompatible with special revelation. ${ }^{10}$ In demanding greater specificity in such moments of revelation, therefore, Schwöbel appears to be treating the former as a faulty or inadequate version of the latter. Indeed, it seems that the problem with general revelation from Schwöbel's point of view is that it isn't special revelation. ${ }^{11}$ By contrast, I would want to maintain that they are two very different but consonant things - which is why they have different but related names - based on contrasting kinds of data, involving different modes of knowing, each with its own distinct uses and values.

I emphasize the value of these vesperal intimations, as one of the ways in which those opposed to general revelation or natural theology attempt to nudge such experiences offstage is by suggesting that their lack of theological specificity necessarily entails a loss of significance. ${ }^{12}$ And yet, as William James amongst many others has noted, whilst mystical intimations of something transcendent are typically marked by transience and ineffability, they are nonetheless capable of profound effects and can transform our ways of being in the world. As James writes: 'They are illuminations, revelations, full of significance and importance, all inarticulate though they remain; and as a rule they carry with them a curious sense of authority for aftertime'. ${ }^{13}$ This was of course the case with Paul Tillich, whose revelatory encounter with a work of art in a Berlin museum ${ }^{14}$ lacked the sort of specificity that Schwöbel desires ("As I stood there, bathed in the beauty its painter had envisioned so long ago, something of the divine source of all things came through to me'); and yet, as Tillich goes on to explain, 'That moment has affected my whole life, given me the keys for the interpretation of human existence, brought vital joy and spiritual truth'. ${ }^{15}$

\footnotetext{
${ }^{10}$ My project in Extravagance may therefore be seen as a form of natural theology, which as Alister McGrath notes, is concerned amongst other things with the sense that 'the natural world is able to signify, intimate, or disclose, no matter how provisionally, a transcendent reality which lies beyond it' (Re-Imagining Nature: The Promise of a Christian Natural Theology (Oxford: Wiley \& Sons, 2017), 7). I would only wish to add to this that I think the arts are capable of such things as well.

${ }^{11}$ Begbie evinces a similar attitude in Redeeming Transcendence (2018), which is a book-length polemic against experiences of transcendence that are not aligned with a Christological or Trinitarian framework. (The section in which he lists the faults of such experiences (37-8) reads a little like a theological game of charades, in which the card that he has drawn has 'general revelation' on it.) Begbie is therefore also highly critical of theological engagements with the arts - like my co-author's, Callaway's and Robert Johnston's - that more optimistically value such experiences as moments of fecundity, which can sunder our quotidian vision and ignite or nourish a sense of something beyond it.

${ }^{12}$ Attempts to discredit experiences of general revelation typically evince a sort of all-or-nothing logic, especially with respect to ideas about knowing, in suggesting that if an experience doesn't match up to the 'all' of special revelation then it is too equivocal, too dangerous, and more trouble than it's worth.

${ }^{13}$ The Varieties of Religious Experience (Cambridge, MA: Harvard University Press, 1985), 302. For an excellent recent defence, see Robert Johnston, God's Wider Presence: Reconsidering General Revelation (Grand Rapids: Baker Academic, 2014).

${ }^{14}$ Botticelli's tondo 'Madonna and Child with Eight Angels', c. 1478.

15 'One Moment of Beauty', in On Art and Architecture, ed. John and Jane Dillenberger (New York: Crossroad, 1987), 234-5.
} 
My counter-question to Schwöbel then is: what if the experience or sense of transcendence lacks the kind of specificity that he would like? What if things are more tangled or 'messy', as they are in the examples Epstein holds up, than a model of hygienic particularity would prefer? Are we simply to dismiss such events? As I shall explain in a moment, I have no objection to the weighing up of these experiences after the fact against a particularized theological framework; what I worry about though is the insistence, prevalent in Begbie's work, that the experiences themselves should exhibit more particularity - which is to say a Christological or Trinitarian particularity - in order for them to be considered legitimate or valuable. For as my co-author has argued so persuasively, the pre-setting of exclusive formal criteria for how God might choose to disclose Himself to us - or how we might open ourselves to a God who is always already addressing Himself to us - risks subjecting the divine to propositional confinement and writes the possibility of encountering that God out of vast tracts of human experience. ${ }^{16}$ It is also surely rather un-biblical. ${ }^{17}$

In contrast to Schwöbel and Begbie therefore - both of whom call for greater specificity and adopt a more all-or-nothing stance towards experiences of revelation - what I think is needed is something akin to that daring but discerning hospitality to mystery that John Keats referred to as 'negative capability'; that is, the willingness to dwell in vulnerable openness with indeterminacy and to hold oneself in 'uncertainties, Mysteries, doubts', without any 'irritable reaching after fact and reason'. ${ }^{18}$ Keats is of course talking about the ability to hold onto an intuition or glimpse of truth in relation to artistic creation, as opposed to those who would 'let go by a fine isolated verisimilitude caught from the Penetralium of mystery, from being incapable of remaining content with half-knowledge'. ${ }^{19}$ However, I want to suggest that this ability to dwell in 'uncertainties, Mysteries, doubts' and to remain content with 'halfknowledge' is vitally important in matters of religion too. For in this way, without expecting such experiences to give us all the answers, and whilst still recognizing the need for special revelation, we can leave ourselves open to and allow ourselves to benefit from those intimations of golden being that can awaken, sustain, enrich or transfigure a life of faith. ${ }^{20}$

The usual objection to this sort of openness is that it is risky and leaves us vulnerable to deception or idolatry - which is of course true. Though I would first of all argue that there

\footnotetext{
${ }^{16}$ See, for instance, God and Enchantment of Place: Reclaiming Human Experience (2004).

${ }^{17}$ What I mean by this is that, although Begbie underscores his approach's strict adherence to Scripture (which is a strict adherence to an interpretation of Scripture) and castigates others for their looseness in this regard, in another sense it departs quite sharply from the world of the Bible, in that his criteriological approach to revelation owes more to the practices of Enlightenment rationalism than the ways in which God discloses Himself in the Bible. As Russell Re Manning argues, it was a theological quest for disciplinary purity, rather than a fidelity to Scripture, that led to the 'eclipse' of natural theology in the modern era ('Natural Theology Reconsidered (Again)', Theology and Science, 15:3 (2017)). On the scriptural endorsement of natural theology, see Michael Sudduth, The Reformed Objection to Natural Theology (Basingstoke: Ashgate, 2009), which concludes as follows: 'Since Scripture affirms both general revelation and the natural knowledge of God, there is a scriptural justification for the project of natural theology' (222). See also James Barr's withering critique of Karl Barth's dogmatic refusal of natural theology in Biblical Faith and Natural Theology (Oxford: Oxford University Press, 1993).

${ }^{18}$ Letter to his brothers, George and Thomas, 21 December 1817, in Keats's Poetry and Prose, ed. Jeffrey Cox (New York: Norton, 2009), 109.

19 Ibid.

${ }^{20}$ A helpful framework in this connection is provided by Newman's writing on the 'illative sense', expounded in An Essay in Aid of a Grammar of Assent (1870). Very briefly, Newman argues that a collection of weak evidences, which may individually be insufficient to furnish a conviction, can, when taken all together, strongly point in a certain direction and cumulatively persuade us of its validity. (The usual analogy is the strength of a rope, which is constituted by the braiding together of multiple weak fibres.) What I am suggesting, then, is that it may be helpful to think about moments of general revelation as part of a larger possible collection of converging data (including Scripture, reason, testimony and experience etc.) and not as an isolated event that on its own is expected to answer all our questions or bear all the weight. One of the advantages of this way of thinking about faith is that it at once preserves the weakness as well as the value of these enigmatic intimations of transcendence.
} 
is something risky in all acts of faith (just as there is in the refusal of faith). ${ }^{21}$ What's more, Scripture recurrently encourages us to cultivate precisely this sort of risky hospitality in the face of unknown visitations. In William James's terms, it urges us to keep our doors and windows open. ${ }^{22}$

I raise all of this here, as it relates to the other thing that Schwöbel overlooks - namely, the alternative model of particularity proposed in the book, which is intended to safeguard, without circumscribing, the openness to possibilities at the centre of our approach. For although we demur from the kind of pre-emptive specification that Begbie demands, this doesn't at all mean we are dispensing with the need for discernment or theological criteria for evaluating the sense of transcendence. Instead, I propose that the criteria of evaluation should be at the other end of the interpretive process, after rather than before the experience, in light of its fruits. ${ }^{23}$ For whilst I see the importance of being particular, I don't see why this needs to take place in advance. To the contrary, rather than peremptorily laying down entrance requirements, I think we should begin with hospitality; and as Jean-Luc Nancy avers: 'The first hospitality is nothing other than listening, ${ }^{24}$

There are several positive and negative reasons for recommending this methodological reversal. To begin with the latter: one of the consequences of predetermining approaches to music like Begbie's - that is, approaches that wish to assign systematic theological significance to particular forms or features of music ahead of the event of listening - is that they end up with a 'one-size-fits-all' template of essentialized evaluations. ${ }^{25}$ Thus, for example, incomplete forms in music are valorized because they evoke an eschatological horizon, whereas closed harmonies are disparaged because they fail to convey the 'excess' or ceaseless overflow of intratrinitarian self-giving. ${ }^{26}$

\footnotetext{
${ }^{21}$ As James Barr observes, even if there were no natural theology in the Bible but only revealed theology, the latter 'cannot produce a total picture of God except through the activity of the theological interpreter. But that interpreter must use his own thoughts, reason, instincts, and experience in order to grade, to select, to bring together, to order, to raise to higher levels the material with which he or she works. The interpreter will have to draw conclusions from the scripture which it itself does not make express; and this drawing of conclusions will depend on the categories, methods, and anterior preferences of the interpreter. Thus the theologian who fully denies natural theology may nevertheless be constructing an "idol" out of scriptural materials just as much as the natural theologian is constructing an "idol" out of other materials" (Biblical Faith and Natural Theology, 152).

${ }^{22}$ Some Problems of Philosophy: A Beginning of an Introduction to Philosophy (Lincoln, NE: University of Nebraska Press, 1996), 100. Later on, in his discussion of pluralism, James makes a similar point in describing the universe as 'unfinished, with doors and windows open to possibilities uncontrollable in advance' (141).

${ }^{23}$ This 'fruits' criterion obviously has a scriptural foundation, and according to John Hick, it is 'the universal criterion of the authenticity of religious experience' (The New Frontier of Religion and Science: Religious Experience, Neuroscience and the Transcendent (Basingstoke: Palgrave, 2006), 51).

${ }^{24}$ Listening, trans. Charlotte Mandel (New York: Fordham University Press, 2007), 9.

${ }^{25}$ In his helpful classification of different methodologies in theology and the arts, Gordon Lynch describes this sort of approach as an 'applicationist' theological method, which he associates with Karth Barth and defines as follows: 'The applicationist approach proceeds from the basis of a preformed theological agenda and set of beliefs and listens to the "voice" of [art] simply with the intention of evaluating the extent to which it fits with this agenda or those beliefs' (Understanding Theology and Popular Culture (Oxford: Blackwell, 2005), 104).

26 'Created Beauty: The Witness of J.S. Bach', in The Beauty of God, 32. The rationale that Begbie provides for this approach raises a lot more questions than it answers. Very briefly, in attempting to establish a Christian understanding of beauty, which is free from all other cultural adulteration, Begbie argues that beauty should take Trinitarian form, which is to say it should somehow reflect 'the story of Jesus Christ the incarnate Son, living in the Father's presence in the power of the Spirit' ('Created Beauty', 22). This seems like quite a tall order. It also rather uncharitably consigns a huge amount of human experience and culture to the category of the 'not-beautiful'. There are, however, a number of other problems with this proposal. For a start, it strangely assumes that fidelity to the Christian kerygma is a matter of patterning or emblematic correspondence. Furthermore, it assumes that this correspondence can be unproblematically secured even where it involves a translation of a translation across different media (from Scripture to theological precepts to asemantic sonorous forms).
} 
Leaving aside what non-theological musicologists would make of this hierarchization of musical forms, the glaring problem with this sort of approach is that in offering us a prepackaged set of meanings it curtails the polysemic openness of music. Indeed, the result, as Gerald Liu observes, is 'theological ventriloquy, where the musician and music no longer speak for themselves. Instead, they voice preconceived beliefs and doctrines'. ${ }^{27}$ What's more, it evinces a troubling disregard for difference and what I have called 'the listener's share'. ${ }^{28}$ There are several important dimensions to this which can only be briefly summarized here.

In the first place, it leaves aside differences of context and the ways in which musical meaning and value may to some extent be co-constituted by the listener - that is, by what we do with music and what it chiastically does to us. For example, when an excerpt from The Marriage of Figaro is unexpectedly and illicitly played over the PA system in The Shawshank Redemption, its rupturing of the prisoners' quotidian world and the ecstatic sense of freedom it momentarily elicits has nothing to do the lyrical content (which concerns a plot to expose the infidelity of Count Almaviva, in a language the narrator doesn't understand). Rather, its significance is primarily determined by the context and the work's affects - that is, by what it does to or for the prisoners, what it evokes for them, in that situation. As the narrator explains:

I have no idea to this day what those two Italian ladies were singing about. Truth is, I don't want to know. Some things are best left unsaid. I like to think it was something so beautiful it can't be expressed in words ... and makes your heart ache because of it. I tell you, those voices soared higher and farther than anybody in a grey place dares to dream. It was like a beautiful bird flapped into our drab cage and made those walls dissolve away. And for the briefest of moments ... every last man at Shawshank felt free. $^{29}$

It's hard to see how this widely recognized feature of music listening could be reconciled with an approach that pre-specifies the meanings and values of music.

Similarly, in the second place, in seeking to establish meanings in the abstract, it neglects the vital role of performance - as well as sampled re-performance - in the constitution of meaning. One of the examples I give in the book of how a work's performance can radically alter its meaning is The Polyphonic Spree's euphoric cover of Nirvana's 'Lithium'. Another more complex illustration of the 'unfixability' of musical meaning would be James Leyland Kirby's extraordinary work with The Caretaker, on albums such as An Empty Bliss Beyond This World (2011), which stitches samples of pre-war ballroom jazz records into new miniature loops of music. These eerily wistful melodic eddyings, which foreground their own patchwork character and turn the crackling acetate into a sort of instrument, sound like music made from memories of music, which imbues them with a peculiar poignancy that is absent in the originals, as our listening is refracted through a deteriorating nostalgic subjectivity. ${ }^{30}$

In the third place, it fails to take account of the ways in which differences of age, class, ethnicity, gender, mental ability and sexual orientation etc. may similarly condition the reception of music. I am particularly sensitive to this at the moment as my six-month-old

\footnotetext{
${ }^{27}$ Music and the Generosity of God, 122. Begbie's own way of describing this sort of procedure - when 'out of a concern for doctrinal orthodoxy, music is not given room to be itself' - is 'theological imperialism' (Resounding Truth: Christian Wisdom in the World of Music (Grand Rapids: Baker Academic, 2007), 21).

${ }^{28}$ The Extravagance of Music, 230.

${ }^{29}$ I would like hereby to acknowledge that there is a reference to The Shawshank Redemption in Deep Focus: Film and Theology in Dialogue, by Kutter Callaway, Craig Detweiler and Robert Johnston (Grand Rapids: Baker Academic, 2019), 142 and 143.

${ }^{30}$ According to Kirby, the piece was inspired by an academic study of patients with Alzheimer's disease, by researchers at the Boston University Medical Center, investigating the ways in which music can enhance the learning of new information.
} 
daughter's musical tastes currently centre around Tchaikovsky's ballets and 'Baby Shark' (doo doo du-do du-do).

Fourthly, it displays a parallel disregard for denominational differences and appears to assume that its own favoured doctrinal loci (or what Begbie rather ominously refers to as 'the controlling truth criteria' ${ }^{31}$ ) are a neutral précis of the scriptural witness which is supposed to be normative for all Christians. As I point out in Extravagance, the problem with this becomes most apparent in Begbie's critical evaluation of composers working in religious traditions other than his own; for what it seems he is criticizing in the music of the Tavener and Messiaen, for example, is their failure to conform to the emphases of a Reformed vision. This is, to my mind, a troubling form of criticism. Indeed, the danger is that, instead of a critical appreciation, we have a theological policing of art. ${ }^{32}$

Finally, it fails to leave room for pragmatic pastoral considerations - about what aspects of the Christian narrative it might, in particular times of need, be appropriate to foreground; for surely what's damaging and what's conducive to a person's spiritual and psychological wellbeing will vary widely according to their experiences and existential circumstances. ${ }^{33}$ Once again, it's hard to see how an approach that provides us with 'readymade' meanings and a hierarchy of aesthetic values, which are supposed to hold for all listeners irrespective of context, could accommodate these kinds of considerations.

The positive reasons for recommending a methodological reversal are more easily summarized, since they are in the main implied by the above. The most obvious advantage of a 'post-hoc' evaluative approach, in light of the effects of music. is that it leaves room for diversity and allows us to take cognizance not only of the ways in which musical performance and the context of reception can play a vital role in the constitution of meaning but also how a range of human differences can condition the reception of music. (I will return to this issue in the discussion of Epstein's paper, which emphatically endorses the need for an approach that recognizes the full range of human experience 'in all its intersectional complexity and variety'.) Moreover, adopting this sort of approach to music also means that the criteria of evaluation can be tailored to the individual's own particular conception of the good, be it religious or secular, which allows us to make judgments about religious experiences more ecumenically in terms of their congruence with the teachings of any particular tradition. As I have argued in Extravagance, postposing the act of evaluation in this way need not, as Begbie seems to think, entail an elevation of aesthetic over theological judgments; though in contrast to predetermining approaches it does involve making room for diversity in determining the sort of theological perspective to which one appeals, and it does endorse a pluralistic vision that honours the inflections of lived experience.

I have retrodden a certain amount of ground in the foregoing discussion in an attempt to clarify the problems with Begbie's applicationist approach and the advantages of a 'posthoc' alternative, for whilst Schwöbel acknowledges the issues we raise about diversity, context and cultural conditioning, and although he speaks of 'mutual resonances', he seems in the end simply to reaffirm Begbie's demand for further specificity without explaining how such a predetermining approach could deal with any of these problems.

\footnotetext{
31 'Created Beauty', 32.

${ }^{32}$ Begbie doesn't use these terms, though he openly admits that he sees it as the role of theology to maintain law and order in the arts (Redeeming Transcendence, 128).

${ }^{33}$ Ewan Bowlby, one of our PhD students at St Andrews, is currently doing some fascinating work on the ways in which particular forms and features of art can play a role in providing emotional, psychological and spiritual care for cancer patients, by offering them narratives, characters and imagery that may help them to reflect on and reframe their experiences. This is just one example of a situation in which it is surely right for pastoral concerns to play a role in determining which aspects of the gospel and what kinds of art should be pragmatically privileged.
} 
It is clear from Kutter Callaway's witty contribution that he is an accomplished scholar of film, as he vividly evokes a meta-cinematic scenario in which he is the sympathetic star of a romcom about Kutter's luckless travails in scholarly courtship. ${ }^{34}$ In contrast to Schwöbel though, Callaway proposes a different way of responding to Begbie's spurning of dialogical suitors and that is to stop engaging with him. ('Conscious uncoupling' is Callaway's nicely facetious phrasing for this, à la Gwyneth Paltrow and Chris Martin. Personally speaking, I can't say I've ever thought of my relationship with Begbie in quite this way; however, I take the point.) ${ }^{35}$

I'm afraid my own view is rather more prosaic - and a little ambidextrous. On the one hand, having called attention to the classical elitism and methodological drawbacks of Begbie's approach, as part of an attempt to open up a space for a more ecumenical and hospitable way of thinking about the relationship between music and theology, I wasn't planning on any sort of sequel - unless of course Begbie were suddenly to show an interest in the work of Nicki Minaj or the Sleaford Mods. On the other hand though, for the purposes of this particular project, it seemed important to engage in detail with Begbie's work (and this relates to what Schwöbel says about the book paying a compliment to Begbie); for in light of his influence within the field, I felt it was necessary to contest the impression he gives that popular music is an inferior artform, of little or no religious value, and to challenge his increasingly negative comments about other ways of doing theology and the arts.

With regard to Callaway's claim that Begbie's work is allowed to 'over-determine the terms, conditions, scope, and even the imaginative possibilities' of the project, I more straightforwardly disagree and think the criticism is itself overstated. I can only speak in detail about my part of the book, but I think its interest in affect, affordance, the epiphanic moment, varieties of post-secularism, spilt religion, enchantment, kitsch, lightness, the ludic, the Ricoeurian world 'in front of' the text, productive underdetermination and the obsequiousness of pop, for example, come from elsewhere and are developed in ways that are not determined by Begbie's work. In making this claim, Callaway also passes over the entire first half of the theoretical section, which is devoted to the writings of Roger Scruton, which seems to have attracted less attention but which is just as instrumental in setting up the subsequent discussions.

There is another side to Callaway's lament though, and this concerns our failure to engage with his own work and the writings of some of his colleagues at Fuller. In essence, it seems he wishes we'd written a different book, on another subject, in which Kutter Callaway featured more prominently. I am sorry to hear he feels peeved about this, especially since I have read and very much enjoyed his Scoring Transcendence book. I didn't refer to this in Extravagance as Callaway's book is about film music, which is a peripheral concern in ours and didn't seem to warrant an excursus into the secondary literature on the subject. ${ }^{36}$

\footnotetext{
${ }^{34}$ This was much more prominent in the original version of the paper.

${ }^{35}$ As my co-author responds to Callaway's point about empirical research, I shall only add here that, whilst I still see the need for other kinds of study as well, I agree that this sort of research can play an important role in theology and the arts, which is why I draw attention to the existence of such work in Extravagance (177) and argue that it provides us with a valuable alternative hermeneutic vantage for thinking about the revelatory and transformative potential of music. It may also be worth noting that we currently have several doctoral students in ITIA who are working on projects involving empirical research, including one - by Kimberley Anderson - on progressive rock and spiritual experience.

${ }^{36}$ One of the challenges of writing a book that seeks to offer a sustained consideration of both popular and classical music, in light of another set of disciplinary concerns, is the difficulty of fitting things in. This challenge was exacerbated in our case, as shortly before the MS was due to be submitted, we were asked to cut it by 20,000 words, which meant a lot of material - including some readings of musical examples but also discussion of other scholarly works - sadly (for us, at least!) had to go.
} 
With regard to Callaway's widening of this complaint - which concerns 'what goes unspoken and unsaid' - to include other members of the 'Fuller school', 'who are, in many ways, already charting new paths along the very trajectories [Brown and Hopps] describe', this seems rather strained to me, since of the five books he cited as examples and displayed with PowerPoint in his talk, two are about film, ${ }^{37}$ one is about iconoclasm and iconophilia, one focuses in particular on the visual arts, and the one that does include an extended discussion of music (co-written by Kutter Callaway) was published in April 2019, a year after The Extravagance of Music was published. This is quite a stretching of the word 'already'. ${ }^{38}$ Indeed, according to the logic of Callaway's complaint, the irresistible question now becomes, not why didn't we clairvoyantly refer to Callaway's book on the aesthetics of atheism, but why doesn't it refer to ours, which discusses a few of the same artists and considers the value from a religious perspective of art that diverges from the church's teachings?

In order to uphold the second part of his complaint, Callaway has to downplay the widespread references in Extravagance to two eminent members of the 'Fuller school' namely, William Dyrness and Robert Johnston. (According to Callaway, although we do engage with the work of Dyrness and Johnston, we do not do so in a 'truly substantive' way.) Hmm. This is a pity - and a rather surprising complaint - as my own work has been significantly influenced by the writings of Dyrness and Johnston, and I sought to indicate this debt in the book.

Of course, we do refer to a wide range of thinkers who were already (in the oldfashioned sense of 'before') exploring approaches that diverge from Begbie's - such as June Boyce-Tillman, Michael Bull, Frank Burch Brown, Tia DeNora, Heidi Epstein, Alf Gabrielsson, Lawrence Kramer, Gordon Lynch, Christopher Partridge and Richard Viladesau, to name but a few. (My co-author is too modest to mention it himself, but the first of his three volumes on widening sacramentality and art's ability to engender religious experience ${ }^{39}-$ which prefigures the kind of approach we adopt in The Extravagance of Music - was published in 2004, some ten years or so before the works that Callaway identifies as 'charting new paths'.) These aren't acknowledged in Callaway's essay - indeed, quite a lot goes 'unspoken and unsaid' in his own piece - perhaps because it would have inconvenienced his claim about 'the whole stream of scholarship' that has supposedly been 'overlooked and unacknowledged' in the book, or perhaps because it might have made it harder to extend his personal sense of grievance into a more general criticism. ${ }^{40}$

Be that as it may, I don't think it is helpful or makes much sense to talk as he does about the 'Fuller school' or the 'St Andrews school'. Do all scholars at these institutions speak as one or advocate a single approach? This certainly isn't the case at St Andrews (!) - and I think the School is better for it. (We don't have to look far to find evidence that things are much more heterogeneous; for The Extravagance of Music includes a substantial and distinguished contribution from the 'Indianapolis school' (Frank Burch Brown) and the 'St Andrews school' of course includes Christoph Schwöbel, whose views seem closer to the 'Duke school' than the book's St Andrews authors'.) My point is that whilst Callaway attempts, for whatever reason, to pit Fuller and St Andrews against each other, I see things as much more dialogical

\footnotetext{
${ }^{37}$ One of these is co-written by Kutter Callaway and the other includes four essays by Kutter Callaway.

${ }^{38}$ In the version included in this volume, Callaway has changed one of the books he cites as an example, substituting Deep Focus: Film and Theology in Dialogue, by Kutter Callaway, Craig Detweiler and Robert Johnston (published in 2019), for Maeve Louise Heaney's Music as Theology. I have read and admire all of the works that Callaway mentions; however, in a book already stretched by its dual focus, there obviously isn't room to discuss everything within the wider interdisciplinary field of theology and the arts.

${ }^{39}$ God and Enchantment of Place.

${ }^{40}$ This aspect of Callaway's paper has been toned down in the version included in this volume; however, the original talk delivered at the conference included the following: 'The problem here is not that my feelings are hurt because they forgot to mention me - I mean, my feelings are hurt, but I'll get over it'.
} 
and constructively intertwined. ${ }^{41}$ In the spirit of such collegiality, I shall endeavour not to hold it against Callaway that he doesn't engage anywhere in his work on film with my as yet unwritten book on kitsch music.

If Schwöbel advocates further dialogue and Callaway proposes a 'conscious uncoupling', Heidi Epstein is calling for even more extensive critique of conservative theological approaches like Begbie's. Since I'm not quite sure if it will be possible at once to continue, cease and extend the engagement with Begbie's work, I fear I will inevitably disappoint someone! The burden in the latter case has thankfully been lightened though, as Epstein herself provides us with an excellent outline of the sort of extension she has in mind. This proposed extension pertains in particular to the field of critical musicology, and its scope is indicated by Epstein's opening question: 'why exclude the possibility that divine extravagance infuses critical musicology?' I'm sorry to pull the rug from beneath this so soon, but I'm afraid the short answer is that I don't. The argument I set out in the Introduction and refer back to briefly in chapter 5 is aimed at particular practitioners of critical musicology and not at critical musicology as such. ${ }^{42}$ Indeed, what I argue for - and what I suggest Kramer has brought into view, even as he shows little interest in pursuing it - is the possibility of 'a religious form of critical musicology'. ${ }^{43} \mathrm{I}$ therefore wholeheartedly agree with Epstein that critical musicology can and should be a theological ally or even an 'apologist for divine extravagance'; and I am grateful to her for demonstrating that that there are signs that this is already underway.

My argument, to be clear, is against Kramer and other pioneers of critical musicology who in standing up for music's 'social meanings' - that is, its embodied, mediated and situated character - exhibit an animus towards models of listening that celebrate the moment of sublime reverie or the sense of transcendence that music can elicit, presumably because they saw such experiences as a form of 'unworldly' escape, whereas what they wanted to foreground was the obverse of this - namely, the embedded this-worldly nature of musicking. ${ }^{44}$ I chose to focus critical attention on Kramer in particular, even though I agree with his views on the social character of music, because, across a series of studies, he has set himself against any talk of music's ineffability, which he sees as 'a relic of a certain nineteenth-century vogue for sentimental metaphysics'. ${ }^{45}$ Of course, he has a point in claiming this; but what he leaves aside in sweeping it away as only this is the possibility that for some the sense of transcendence that can be experienced in music - for audiences in the nineteenth century but also, importantly, for

\footnotetext{
${ }^{41}$ Oliver Crisp, once a member of the 'Fuller school', is now a member of staff at St Andrews; and Natalie Carnes, who has a PhD from the 'Duke school' and currently belongs to the 'Baylor school', has twice brought students to St Andrews for a semester and on both occasions was a regular attender of the ITIA seminar.

${ }^{42}$ My comments, for example, about an 'allergy to transcendence' are not addressed to critical musicology as a whole. This is - pace Epstein - a misreading and a slight misquotation of my point. What I actually say is that Lawrence Kramer's allegiance to a form of closed-world materialism (which he openly acknowledges in a number of publications) 'may explain his allergy to the idea of transcendence' $(5, \mathrm{n} .18)$. The allergy to which I refer is his. It is true that in referring back to this discussion I speak in a more generalized way about 'the widespread allergy to transcendence in contemporary musicology' (173). However, this still isn't aimed at the field as a whole, and its widening is based on references in the earlier discussion to the work of Richard Leppert and Susan McClary (4-7). The particularized nature of this critique is also made clear, or so I thought, by the comments on page 175 about 'the disparaging accounts of [transcendence or aesthetic contemplation] in certain strands of critical musicology' [emphasis added].

${ }^{43}$ The Extravagance of Music, 9.

44 A counter-example which I acknowledge in Extravagance of someone working in the field of critical musicology who emphasizes the social meanings of music whilst affirming the possibility of experiences involving the supernatural is Christopher Small, who coined the useful but somewhat ungainly phrase 'musicking'.

${ }^{45}$ The Thought of Music (Oakland: University of California Press, 2016), 46.
} 
listeners today - might be a religious or quasi-religious event. ${ }^{46}$ For, as I seek to show in Extravagance, such experiences of 'escape' needn't be thought of in negative terms, as a kind of aesthetically induced concussion or a condition of vacancy that lacks any positive lure of its own and so is only significant as a 'turning away'. Indeed, for those more open to religious possibilities, the experience of transcendence tends to be conceived as a positively motivated 'turning towards' - that is, as a 'freedom to' at least as much as it is a 'freedom from' - which is typically associated with a movement into I-Thou relation or a realization of divine presence that entails an expansion or intensification of being. As such, for the believer, rather than constituting a withdrawal from the real, the experience of transcendence is an opening of the self to an ultimate reality, which exceeds but opens into our world.

At the same time though, in accord with the insights of critical musicology, I wish to affirm that such experiences are socially constructed events, and that it is possible to have religious experiences in which a sense of something transcendent is disclosed that are embodied and embedded in this world. I therefore agree with Epstein - against theologians who espouse models of revelation that seek to side-step the mediated character of human experience, and against certain practitioners of critical musicology who presuppose a beyondless plane of immanence and so assume that any talk of transcendence is a mystification - that critical musicology can help to bear witness to the extravagance of the divine.

Something of what this might look like in practice is exemplarily set out in Epstein's essay, which focuses in particular on the 'power/knowledge dynamics at work within theologies of music' and the ways in which critical musicology can liberate and vindicate what Foucault refers to as 'subjugated knowledges'. A key feature of this, as Epstein points out (quoting Jorgensen and Phillips), is the contestation of 'discourses that seek "to fix meanings in particular ways, and thereby foreclose all other meaning potentials"'. This is manifestly germane to our project, which on the one hand attempts to recover the polysemic and extravagant openness of music, which has been corseted and obscured by systematizing theological approaches, and on the other hand stands up for 'naïve knowledges' or forms of art 'located low down on the hierarchy' beneath the required level of formal complexity.

Whilst these are key features of Extravagance's project, Epstein does indeed 'expand [its] discursive breadth' by proposing five socio-political 'lenses' that help us to discern 'revelations of divine extravagance' in 'wayward', 'outlaw' or 'risqué' experiences. Aside from showing in compelling detail how 'music's social meanings are crucial building blocks for constructing musico-theological models of divine extravagance', this focussing of attention on 'messy' revelations is particularly important, as it challenges 'the exclusionary politics of limiting the scope of divine self-disclosure'. Thus, Epstein's essay - which announces itself as a 'cheeky' inquiry - is, I suggest, a welcome supplement that sharpens the critical edge of the book and furthers its 'ecumenical expansion of music's theological significance'.

Like Epstein's, though very different in tone and focus, Tony Alonso's paper argues for a wider or even more radical openness in relation not only to the revelatory and transformative possibilities of music but also the devotional potential of religious kitsch. This is, as it were,

\footnotetext{
${ }^{46}$ To be sure, the usual reading of the nineteenth-century slide of religion into the aesthetic is that 'the religious "dies" and the nameless afterlife of its transposed transcendence is ambiguously resurrected in art' (William Desmond, Art, Origins, Otherness: Between Philosophy and Art (New York: SUNY Press, 2003), 267). However, I would suggest a little more positively that the aesthetic sphere might residually preserve religious possibilities that have ceased to compel assent in other contexts. Furthermore, are we not witnessing in the tendency known as the 're-enchantment of the West' something of a reversal of this earlier slide, in that art now for many people leads them towards religious possibilities? (On this, see William Dyrness, Poetic Theology: God and the Poetics of Everyday Life (Grand Rapids: Eerdmans, 2011).)
} 
music to my ears. Indeed, the only thing I disagree with is Alonso's sense that we disagree at all. (I think my own grandmother on my mother's side - who was an Irish Catholic migrant to Liverpool, and who passed on to my mother an unironic devotional fondness for kitschy religious knick-knacks - would have got on very well with Alonso's.)

Alonso's sense of divergence in our views concerns the degree of openness evinced in the book with regard to 'what music is worthy of theological reflection'. According to Alonso, whilst my co-author 'opens the door to the potential for secular music to engender religious experience', I 'swing[...] that door open even wider'; and yet at the same time I somehow also leave it a little closed. As Alonso puts it, I reveal my own "light" limits' as well as 'a soft hierarchy on what music best orients our thoughts toward the divine'. Specifically, these limits are revealed in 'occasional insinuations', 'caveats and qualifications' which suggest that there are in fact some boundaries around what kinds of music may afford religious experience'. How accurate is this impression?

Perhaps the best way of addressing this question is to state my views on the subject clearly and then try to explain why I think Alonso's description of things doesn't quite capture the argument I set forth in the book.

The first thing I should like to make clear, then, is that I don't wish to impose any limits on what sort of music can precipitate religious experience. This is why I don't provide any criteria for defining such limits. This is, as I sought to explain in the book, because "we can never securely determine in advance what stimuli will elicit what affects, so that we cannot with any certainty say what sacred artifact might become an idol or what "intrinsically" profane work of art might serve as an icon and kindle within us intimations of the divine or set us on the path towards "the First Composer"". This is what I mean when I speak about the freedom of affects. (I have personally been moved to a state too deep for tears by The Nolan Sisters' 'I'm in the Mood for Dancing', so I wouldn't want to rule anything out.) However, this affirmation of radical openness is conjoined in my argument with another principle, which does qualify this affirmation, but not in the way that Alonso suggests, nor in a way that constrains this openness - and that principle goes by the name of 'affordance' ${ }^{47}$

As I sought to emphasize in the book, the notion of affordance allows us to think about 'more and less likely correlations' without compromising a radical openness to possibilities. ${ }^{48}$ It allows us, in other words, to think about particular concrete features of music 'in a pragmatic rather than an essentialist manner' and permits us to recognize 'common tendencies or typical effects without according them an ontological foundation and without proscribing their potential entailments'. ${ }^{49}$ In conceding, therefore, that not all popular music 'affords' epiphanic experience, what I am saying is that not all instances of popular music suggestively lend themselves to engendering such states. Off the top of my head, I find it hard to imagine anyone being lifted into a celestial reverie by The Wurzels' 'I Am a Cider Drinker' or Alvin Stardust's 'My Coo Ca Choo'. However, I am not saying that they can't. The principle of affect is

\footnotetext{
${ }^{47}$ I do, as Alonso notes, at one point in my discussion of Scruton's work, allude to the possibility and even necessity of making 'moral distinctions about the value of artworks' (186). What in particular I had in mind was hate speech and the use of art to promote racist, homophobic or misogynistic views, for example. Since such things are a Public Order offence in the UK and are prohibited within the broadcasting industry by the regulatory authority Ofcom, attending to such distinctions is a matter of upholding the law and not a quirk of my methodology. (I wonder if there are any sorts of views or kinds of material that Alonso would think it inappropriate to broadcast in public?) Endorsing the need for such distinctions does not, however, as Alonso suggests, impose a limit on the kinds of music that I think are capable of eliciting religious experience. For I would affirm, as Alonso does at the end of his paper, that even 'abuses that [run] against the deepest impulses of the Gospel' are not incompatible with divine revelation. For further discussion and illustration of this latter point, see David Brown's Discipleship and Imagination and Tradition and Imagination.

${ }^{48}$ The Extravagance of Music, 178.

${ }^{49}$ Ibid., 241.
} 
intended to keep this possibility open. (My remarks about being elevated into a state of expanded consciousness by the muzak in B\&Q were meant to affirm the openness of this principle even in apparently unpropitious cases. ${ }^{50}$ )

What I am talking about is a matter of likelihood or a probabilistic function - which is, I acknowledge, a loose and impressionistic measure, but it is in no way a barrier to the openness I affirm. This is why my definition of 'affordance' includes a proviso: 'Affordances, broadly, are the properties of an object or event that suggestively lend themselves [...] to certain activities or the elicitation of particular states, even though these suggestions are not determinative'. ${ }^{51}$ The example I gave of an unforeseen entailment was twerking to Dvorak, but I'm equally open to trancing to muzak. ${ }^{52}$ The British adult comic Viz was some years ahead of me in affirming this principle, as illustrated by the character called 'Ravey Davey', who is forever being sent into a state of euphorically entranced dancing by the repetitive sounds of things in the urban environment, such as pneumatic drills or the beeping of a lorry in reverse (when he awakes in hospital after being run over by the lorry, he is similarly affected by his life-support machine, whose 'beats' he enthuses are 'kicking it large').

This openness to apparently unlikely possibilities is, however, built into the concept itself, since likelihood in relation to affordances is much less limiting than it might at first seem. This is partly because affordances are relationally constituted and emerge as a result of the interaction between the perceiver and their environment. They are thus, to some extent, constituted in or by the eye of the beholder. This means that likelihood in the context of affordances leaves things open to individual differences. What's more, as research in the field of Psychology has shown, affordances are flexible and are frequently multiple. They are also subject to continuous modification. So if I repeatedly see customers in a state of musically induced rapture in the spanners and wrenches aisle at B\&Q, I will update my sense of its likelihood accordingly. The point is that likelihood is not a once and for all binding evaluation.

Thus, to conclude, I think the openness I affirm is as undelimited as Alonso's ideal; though I would want to ask him in return - if he still has reservations about the principle of affordance - if he thinks that all music, whether it is Palestrina, Chas \& Dave, Lizzo, The Really Terrible Orchestra, Mary Poppins, Plague Mass, Ornette Coleman, the theme to Peppa Pig, The Texas Nazis or Kajagoogoo, is identically likely to elicit religious or other affects? If so, then there is indeed a (soft, light or diaphanous) difference between our views. Either way though, I am grateful for the opportunity to clarify my position - on this and all of the foregoing matters.

\footnotetext{
${ }^{50}$ Alonso refers to this as a 'milquetoast affirmation', which makes it seem like a failure of nerve; whereas I was attempting to balance a sense of possibility - which I emphatically affirm - against a countervailing sense of its unlikelihood. Though perhaps musical epiphanies are a regular occurrence in home improvement outlets in the US.

${ }^{51}$ The Extravagance of Music, 240-1, emphasis added. In the passage Alonso cites in order to suggest, in spite of the larger argument against such things, that I am proposing a hierarchy of musical forms, he cuts short the quotation mid-sentence, excising the vital concessive clause that is part of the point. What I say - after acknowledging that 'certain types of art and music are much more likely to elicit a posture of contemplation or orient our thoughts toward the divine, while others, more redolent of this-worldly concerns, are more likely to keep our thoughts below' - is: 'This is undoubtedly true; though it doesn't rule out the radical freedom or autonomy of affects, which, as Sedgwick and Massumi among others insist, may be unpredictably elicited by a supralogical diversity of causes' (220). In only quoting one of the two principles I affirm in tandem, Alonso subtly but significantly misrepresents my position.

${ }^{52}$ The other bit of evidence that Alonso presents in support of his claim that I residually preserve a musical hierarchy - even as I strenuously argue against it - concerns my use of words such as 'hyperbolic', 'sentimental', 'over-lit', 'tacky' and 'banal'. In response to this I would say that I think he has lost sight of the bigger picture; for I use such words - which I thought my overarching argument would make clear come with an implicit 'what's commonly viewed as' tag - in order to redeem the value of these things. Indeed, in identifying such qualities as affordance structures, I explicitly accord them a positive valency.
} 